\title{
Meslek Yüksekokulu Öğrencilerinin Kariyer ve Girişimcilik Yönelimleri*
}

\author{
Mübeyyen TEPE KÜÇÜKOĞLU** $\quad$ M. Emin BAYNAZOĞLU***
}

\author{
Şayan BERBER ${ }^{* * * * *}$
}

\begin{abstract}
$\ddot{O} Z$
Dünyadaki paradigma değişimiyle adından daha çok söz edilmesine neden olan girişimciliğin; istihdama, yatırıma, ödemeler dengesine ve ülkelerin kalkınmasına katkı sağladiğı bilinmektedir. Bu sebeple "girişimcilik" konusunun dünyanın diğer ülkelerinde olduğu gibi Türkiye'de de ön lisans, lisans, yüksek lisans ve doktora programlarının ders müfredatlarında yer almaya başladığı görülmektedir. Bu çalışmada, İstanbul Yeni Yüzyll Üniversitesi Meslek Yüksekokulunda girişimcilik dersi alan ögrencilerin, kariyer yönelimleri ve bu yönelimlerinde girişimcilik seçeneğinin payın tespit etmek amacıyla, bir soru formu uygulaması gerçekleştirilmiştir. 98 ögrenciden elde edilen geçerli veriler, nicel ve nitel araştırma yöntemlerinin birlikte kullanımı ile analiz edilerek bulgulara ulaşılmıştır. Buna göre, tüm ögrencilerin \%39,80'inin kariyer yönelimi tercihleri özel sektör olurken, girişimcilik kariyeri tercihinde bulunanların oranı ise \%26,53 dür. Girişimcilik kariyerine yönelmek isteyen öğrencilerin \%27'sinin kadın, \%73 'ünün ise erkek olduğu tespit edilmiştir. Kadın öğrencilerin en çok özel sektör kariyeri tercihinde bulundukları, erkek ögrencilerin ise en çok girişimcilik kariyeri tercihinde bulundukları görülmüşstür. Ayrıca kariyer yönelimi tercihlerinde bölümler arasında da farklılıklar olduğu gözlemlenmiştir.
\end{abstract}

Anahtar Kelimeler: Girişimcilik, Girişsimcilik eğilimleri, Meslek Yüksekokulu, Eğitim

JEL Sinıflandirması: I23, I29, L26

\section{Career and Entrepreneurship Orientation of Vocational School Students}

\begin{abstract}
With the paradigm shift in the world; it is known that entrepreneurship contributes to employment, investment, balance of payments and development of countries. For this reason, it is observed that the subject of "entrepreneurship" is starting to take place in the curriculum of vocational schools, undergraduate, graduate and PhD programs in Turkey, as in other countries of the world. In this study, a questionnaire was applied to determine the career and especially entrepreneurial tendencies of students who take entrepreneurship courses at Istanbul Yeni Yüzyll University Vocational School. The data obtained from 98 students were analyzed by using the quantitative and qualitative research methods together and some findings were obtained. According to findings, 39,80\% of all students have a career tendency in private sector while the rate of those who prefer an entrepreneurship career is $26,53 \%$. Moreover, $27 \%$ of the students who want to move
\end{abstract}

\footnotetext{
${ }^{*} \mathrm{Bu}$ çalışma 9-11 Nisan 2019 tarihinde düzenlenen ICOAEF'19 konferansında "Girişimcilik Dersi Alan Öğrencilerin Kariyer Yönelimleri: Meslek Yüksekokulu Öğrencileri Üzerine Bir Araştırma" adlı çalışmanın gözden geçirilmiş genişletilmiş halidir

${ }^{* *}$ Dr.Öğr. Üyesi, Trakya Üniversitesi KYÇUBYO, Uluslararası Ticaret Bölümü. mtepekucukoglu@trakya.edu.tr, ORCID bilgisi: 0000-0002-3717-4165

***** Dr.Öğr. Üyesi, Trakya Üniversitesi KYÇUBYO, İşletme Bilgi Yönetimi Bölümü. meminbaynazoglu@trakya.edu.tr, ORCID bilgisi: 0000-0003-1978-1348

***** Dr., sayan.berber@gmail.com, ORCID bilgisi: 0000-0002-7897-7335
}

(Makale Gönderim Tarihi: 24.07.2019 / Yayına Kabul Tarihi:16.03.2020) 
towards entrepreneurship career are female and $73 \%$ are male. It was observed that female students prefer mostly private sector and male students choose entrepreneurship. In addition, there are differences between the departments of students in career orientation preferences.

Key Words: Entrepreneurship, Entrepreneurship tendency, Vocational School, Education

JEL Classification: I23, I29, L26

\section{GíRIŞ}

İnsanlık tarihinde, avcılık ve toplayıcılıktan yerleşik hayata geçildiği "Neolitik Çă̆"'da tarım aletlerinin icat edilmesi ve bu sayede bitki ve hayvanların ıslah edilmesi sayesinde, girişimcilik fikrinin ortaya çıtığı düşünülmektedir. Yaklaşık onikibin yıl öncesine tarihlenen bu dönemden itibaren, girişimcilik konusunda din adamları ve tüccarlar tarafindan bireysel ve toplumsal alanda bazı çalışmalar yapıldığı anlaşılmaktadır.

Ekonominin, gelir ve üretim kaynaklarının önemli bir noktasında bulunan sanayi ve dalları uzun zamandır bir değişim ve dönüşüm içerisinde olmuştur (Özdoğan, 2019). 18. yüzyılın sonunda, buhar makinesinin icadı ve sonrasında geliştirilmesi ile ilk endüstri devrimi başlamıştır. 20. yüzyılın başında, elektrikli makinelerin otomobillerin seri üretiminde kullanılması ikinci endüstri devrimini başlatmıştır. 70'li yıllarda, makinelerin otomasyonuyla birlikte endüstride yeni bir dönem başlamış ve bu sayede insan hataları en aza indirilmeye çalışılmıştır. 2011 yılında, Almanya tarafindan Hannover fuarında tanıtılan ve Endüstri 4.0 olarak adlandırılan süreç ise günümüzde devam eden sanayi teknolojilerinin başlangıcı olmuştur (Eğilmez, 2018).

Özellikle son üç yüz yılda girişimci düşünce yapısı sayesinde ortaya çıkan tüm bu gelişmeler, girişimciliğin bireysel ve toplumsal gelişme için ne kadar önemli olduğunu gözler önüne sermiştir. Konunun önemi doğrultusunda gelişen bilinç, beraberinde girişimcilik eğitiminin yükseköğretim ve hatta orta öğretim düzeylerinde yaygın şekilde uygulanmaya başlanmasını sağlamıştır.

Girişimcilik eğitimi alan öğrenciler, bu konuda bilgi sahibi olarak belirli bir farkındalığa sahip olmaktadırlar. Bu nedenle bu çalışmada, girişimcilik dersi alarak belli bir farkındalığa eriştiği düşünülen İstanbul Yeni Yüzyıl Üniversitesi Meslek Yüksekokulu Bankacılık ve Sigortacılık, Dış Ticaret, Halkla İlişkiler ve Tanıtım ile Lojistik Programı son sınıf öğrencilerinin, kariyer yönelimleri ve özellikle girişimcilik kariyerine yönelimleri ve bu yönelimin altında yatan sebepler araştırılmaktadır. Araştırma kapsamında oluşturulan soru formu vasitasıyla, öğrencilerin üç farklı kariyer yöneliminden (girişimcilik, özel sektör veya kamu sektörü) hangisini tercih ettiklerini belirtmeleri, sonrasında bu tercihlerinin arkasında yatan sebepleri saymaları istenmiştir. 98 geçerli görüşme formu üzerinden, nicel ve nitel analiz yöntemlerinin marifetleri birleştirilerek analiz yapılmış ve çeşitli sonuçlara ulaşıılmıştır.

\section{KAVRAMSAL ÇERÇEVE}

\section{A. Girişimci ve Girişimcilik Kavramları}

Girişimcilik kavramı, istihdam ve kalkınmaya yaptığ 1 doğrudan katkılarından dolayı bugüne kadar birçok farklı akademisyen tarafından incelenmiştir. Literatüre girişi ise Fransız iktisatçı Richard Cantillon'nun, 
Fransızca bir fiil olan "Enterprendre" (bir işi yapmak) olarak yaptığı tanımlamaya dayanmaktadır. Jean Baptiste Say ise, Cantillon'un tanımına "üretim faktörlerini bir araya getirme" parçasını da ekleyerek, tanımı genişletmiştir (Stevenson \& Harillo, 1990). Girişimcilik kavramının, ilk defa 1910 sonrası basılan kitaplarda yer almaya başladığı görülmektedir. "Yaratıcı yıkım" ve "yenilikçilik" gibi kavramları literatüre katan, Joseph Alois Schumpeter, bu durumu 1911 tarihli, "The Theory of Economic Development: An Inquiry into Profits, Capital, Credit, Interest, and the Business Cycle" adlı eseriyle doğrulamaktadır (Pazarcık, 2016).

Girişimcilik kavramı ile ilgili bugüne kadar farklı tanımlamalar yapılmış olması, üzerinde fikir birliğine varılan net bir tanımlamaya gidilmesini güçleştirmektedir. Pratiği daha da öncelere uzanan girişimciliğin, kavramsallaştırılmasının ilk defa yapıldığı 1732'den bu yana, alandaki kuramcılar girişimciliğe farklı yaklaşımlar geliştirme çabası içerisinde olmuşlardır. Girişimcilikle ilgili iki ana yaklaşımdan bahsedilebilir. Bu iki ana yaklaşımdan ilki, bireyleri yeni işletme kurmaya yönelten süreçlere odaklanırken; diğeri ise, girişimciliği "yenilikçi işletme" ile ilişkilendirmektedir (Eryılmaz, 2015).

Girişimciler, ortaya yeni bir ürün veya hizmet koymak için risk almaktadır. Başka bir deyişle girişimci, firsatları araştıran ve bu firsatları hayata geçirmek için risk alan kişidir. Girişimcilik kavramı ise, girişimci faaliyetlerin gerçekleştirildiği sürece verilen isimdir. $\mathrm{Bu}$ faaliyetlerin içinde piyasadaki firsatları sezme, onları hayata geçirmek için risk alma ve inovatif bir ürün veya hizmet ortaya çıkarmak gibi bileşenler bulunmaktadır. Bu sebeple ticari kuruluşların faaliyete geçmesi ve yenilikçi ürün veya hizmetlerin ortaya çıkarılması, girişimcilik bileşenleri arasında değerlendirilmektedir.

Baumol (1968)'a göre, girişimcinin işlevi yeni fikirler bulmak ve onları hayata geçirmektir. Girişimci faaliyet, planlı, dolayısıyla kasıtlı bir davranışı temsil eder (Krueger \& Carsrud, 1993). Girişimcileri, girişimci olmayanlardan ayıran en önemli özellik, başarılı olmak için tüm olasılıkları değerlendirme azmi ve isteklilikleridir. Girişimcilik, dinamik bir vizyon ile değişim ve yaratma sürecidir. Girişimcilikte yeni fikir ve yaratıcı çözümler ortaya koymak için, enerji ve tutkuya sahip olmak gereklidir. Çünkü girişimciliğin temel bileşenleri, zaman ve kariyer açısından hesaplanmış riskleri alma istekliliğini içerir.

Bir girişimcide bulunması gereken en önemli özellikler ise; etkin bir girişim ekibini yönetme yeteneği, yaratıcı beceriler ve sağlam bir iş planı oluşturma becerisidir. Daha da önemlisi başkalarının kaos, çelişki ve kafa karışıklığ 1 olarak gördügü, firsatları tanıma vizyonudur (Kuratko, 2005). Bir girişimci, sahip olduğu potansiyelini tecrübelerine dayandırarak, yeni açılımlar yapmak için kullanır. Girişimciler, risk ve tehlikeleri analiz ederek, olası firsatları fark etme konusunda diğerlerinden ayrışırlar (Iyer, 2016).

\section{A. Girişimcilik Eğitiminin Yükselişi}

Girişimcilik, oluşumu itibariyle belli koşullara bağlı karmaşık bir sosyoekonomik olgudur. Girişimcilik, mevcut toplumsal yapı içinde gerçekleşen somut bir etkinlikler bütünü olduğundan, şekillenmesi toplumun kurumsal yapısının ve ilişkiler sisteminin niteliğinden bağımsız değildir (İlhan, 2003). Bridge ve 
arkadaşları (1998), sosyo-ekonomik koşulların bireyin kariyer tercihinde önemli olduğunu öne sürmüşlerdir. Toplumdaki değer yargıları ve algılanan roller bireyleri bağlayıcı sonuçlar doğurur. Örneğin, girişimci ailelerden gelen bireylerin benzer bir iş kurdukları ya da mevcut aile işini geliştirdikleri, diğer taraftan işçi ya da memur ailelerden gelenlerin de sıklıkla bu yönde tercih yaparak, verilen koşullara paralel bir iş edinmeye yöneldikleri görülür. Diğer taraftan, küreselleşmeyle birlikte devletin geleneksel rolünün değişmesi ve işlevlerinin yeniden tanımlanması, evrensel üretim ve tüketim kalıplarının giderek yaygınlaşması, uluslararası rekabetin aldığı yeni biçim ve bu bağlamda ortaya çıkan sosyoekonomik sistem, özel girişimciliği global ölçekte yükselen bir değer haline getirmiştir (İlhan, 2003). Bu zihniyet gelişimiyle birlikte, girişimcilik eğitimi de önemli ve yaygın hale gelmiştir (Kuratko, 2005).

$\mathrm{Bu}$ bağlamda girişimcilik eğitimi bireyden topluma yayılarak, toplumun sosyo-ekonomik anlamda ileri yönlü değiş̧iminin temelini oluşturarak, girişimcilik beceri ve tutumlarının geliştirilmesi ve gelecekteki başarı şansını artırmas açısından önemlidir (Yılmaz, 2014). Girişimci bireylerin yetişmesi ve girişimcilik kültürünün oluşumunda, aile faktörünün yanı sıra alınan eğitim de son derece önemlidir. Bireyin öğrenim süresi boyunca almış olduğu eğitimin kapsamı ve felsefesi, girişimcilik ve yaratıcılığını olumlu yönde etkileyebilmektedir (Güney \& Çetin, 2003). Söz konusu eğitimin öğrencilerdeki girişimcilik potansiyelini ortaya çıkarmaya yardımcı olduğu ve kendi işlerini kurmaya yönlendirdiği belirtilmektedir (Yılmaz, 2014). Özellikle girişimciliğin, kamu ve özel sektörün ardından gelen bir kariyer yolu olma durumunu değiștirmeye yönelik çabaların, son yıllarda çok daha fazla gündeme geldiği görülmektedir (Pazarcık, 2016).

Günümüz dünyasında, neredeyse hiçbir ülkede, yükseköğretim kurumlarından mezun olan öğrencilerin tamamına istihdam garantisi sağlanamamaktadır. Bu anlamda, üniversiteden mezun olan öğrenciler için bir düşünce değişimine ihtiyaç duyulmaktadır. Öğrencilerin mezun olduktan sonra "bir iş bul" sendromundan kurtulup, "bir iş zihniyeti yarat" fikrini benimsemelerinin, eğitim hedeflerinin gerçekleşmesine önemli katkı sağlayacağ düşünülmektedir (Delle \& Amadu, 2015). Özellikle Meslek Yüksekokulları, Uygulamalı Bilimler Yüksekokulları ile Turizm ve Otelcilik Yüksekokullarında okuyan öğrencilerin uygulamaya dönük derslerinin, girişimcilik eğilimlerinde olumlu etkiler yarattığı görülmektedir. Bu öğrencilerin eğitim hayatları esnasında, zorunlulukla da olsa iş yaşamı ile temas etmelerinin, onların girişimcilik farkındalıkları üzerinde önemli rol oynayacağını iddia etmek, araştırmalarca da ortaya konulmuş bir tespittir (Pazarcık, 2016). Bu nedenle özellikle ön lisans eğitiminde, ders planlarına girişimcilik derslerinin eklenmesi oldukça faydalı görülmektedir.

Tarihsel olarak bakıldığında, dünyadaki eğitim kurumlarında girişimcilik eğitimi, ilk kez 1938 yılında Japonya Kobe Üniversitesi'nde başlamıştır (Pan \& Akay, 2015). Girişimcilik ile ilgili Amerika'daki ilk eğitim ise, 1947 yılında "Harvard Business School" da verilmiştir (Y1lmaz, 2014). ABD üniversitelerinde girişimcilik ile ilgili derslerin yaygınlaşması da 1970'li yılların başlarında 
gerçekleşmiştir. Bugün dünyanın birçok ülkesindeki 1600 'den fazla üniversitede, girişimcilik ile ilgili yaklaşık 2200 ders okutulmaktadır (Finkle, Kuratko, \& Goldsby, 2006).

Literatürde girişimcilik derslerinin, bu dersi alan öğrencilerin girişimcilik eğilimlerine etkisinin araştırıldığ 1 bir dizi çalışma mevcuttur. Örneğin Sezer (2013b), girişimcilik kariyerine yönelim nedenleri ve girişimcilik dersinin etkisini araştırmak üzere, Sakarya Üniversitesi’nde öğrenim gören ve seçmeli girişimcilik dersi alan işletme bölümü öğrencileri ile bir çalışma gerçekleştirmiştir. Benzer şekilde, Lorcu ve Özduran (2016) da Trakya Üniversitesi öğrencilerinin aldıkları girişimcilik eğitiminin, girişimcilik niyetleri üzerindeki etkisini araştırmışlardır. Her iki araştırma sonuçları da girişimcilik dersinin, bu dersi alan ve almayan öğrenciler karşılaştırıldığında, gençlerin girişimcilik niyetleri üzerinde önemli bir etkisinin olduğunu belirtmektedir. Akın ve Demirel (2015), Aksaray Üniversitesi öğrencileri ile gerçekleştirdikleri çalışmalarında, girişimcilik dersini tamamlayan ve henüz bu dersi almayan öğrencilerin, alg1 ve niyetlerini karşılaştırmışlardır. İstanbul Üniversitesi İşletme Bölümü son sınıf öğrencileri ile gerçekleştirilen bir diğer çalışmada, girişimcilik niyeti ile girişimcilik eğitimi arasında olumlu ilişki saptanmıştır (Doğan, 2015). Benzer şekilde, Galloway and Brown (2002) da gerçekleştirdikleri çalışmada, girişimcilik dersi alan ve almayan öğrencileri karşılaştırarak, girişimcilik eğitiminin girişimcilik istek ve hevesini artırdığ 1 sonucuna ulaşmışlardır.

Farklı ögrenci örneklemlerinde gerçekleştirilen birçok benzer araştırma mevcuttur. Özellikle de üniversite öğrencileri arasında girişimcilik algısı/eğilimini ölçmek, konunun önemi, araştırma uygulanabilirliği, hedef kitleye ulaşılabilirlik, görece düşük araştırma maliyetleri gibi sebeplerle son yıllarda oldukça rağbet görmektedir (Pazarcık, 2016). Fayolle ve arkadaşlarının (2006), Fransa'da girişimcilik dersi alan 23 mühendislik öğrencisi üzerinde gerçekleştirdikleri araştırmaları, girişimcilik eğitiminin bu öğrencilerin girişimcilik niyeti üzerinde güçlü, ölçülebilir bir etkisi olduğunu ortaya koymuştur. Özdemir (2016) tarafından, Türkiye'de üniversitelerde verilmekte olan girişimcilik eğitimleri, üniversiteler tarafından cevaplandırılan anketlerin değerlendirilmesiyle masaya yatırılmış ve ana hatlarıyla değerlendirilmiştir. 93 üniversiteden elde edilen veriler, Türkiye'deki üniversitelerde girişimcilik eğitiminin son beş yılda hız kazandığını göstermektedir

Yelkikalan ve arkadaşları (2010), Türkiye'deki üniversitelerde verilen girişimcilik eğitimi ile dünyadaki diğer üniversiteler arasında bir karşılaştırma yapmıştır. Araştırmacılar, girişimcilik eğitiminin okul öncesi dönemden başlayıp üniversiteye kadar uzanan uzun eğitim döneminde, entegre bir şekilde yer alması yoluyla girişimcilik algısının değişerek, bir girişimcilik kültürü oluşabileceğini belirtmektedirler. Varela ve Jimenez (2001), Columbia'daki üç üniversitede gerçekleştirdikleri araştırmalarında, beş ayrı programda eğitim gören öğrenci gruplarını incelemiş ve en yüksek girişimcilik oranlarının, öğrencileri için girişimcilik rehberliği ve eğitimine en fazla yatırım yapan üniversitelerde elde edildiğini bulmuşlardır. 
Girişimcilik, istihdam ve yenilikçilik başta olmak üzere ekonomik kalkınmada önemli bir rol oynamaktadır (Yelkikalan vd., 2010). Bu nedenle girişimcilik eğitimi birey, işletme ve ülke bağlamında önemli etkiler yaratabilmektedir. Birçok ülkede girişimcilik eğitimi konusuna büyük önem verilmektedir. Nitekim ABD'de gerçekleştirilen bir çalışmada, girişimcilik üzerine eğitim alanların şu özellikleri tespit edilmiştir (Soylu \& Kepenek, 2008);

- Yeni iş kurmada üç kat daha fazla eğilime sahip oldukları,

- Kendi işini kurmak için üç kat fazla istekli oldukları,

- Gelirlerinin y1llık \%27 oranında arttı̆̆1,

- Mal varlıklarının artan gelirle birlikte \%62 arttığ1,

- Çalışılan işte daha fazla iş tatmini yaşadıkları.

II. METODOLOJİ

\section{A. Araştırmanın Amacı}

Eğitim öğretim sürecindeki öğrenciler mezun olduklarında, çeşitli nedenlerle kendileri için uygun gördükleri kariyer alternatiflerinden birini seçmektedirler. Bu seçimlerinde ise birçok faktörün etkili olduğu düşünülmektedir. $\mathrm{Bu}$ doğrultuda araştırmada, girişimcilik dersi alan MYO öğrencilerinin kariyer yönelimlerinin ve bu yönelimlerinde girişimcilik kariyerinin payının belirlenmesi amaçlanmaktadır. Ayrıca öğrencilerin kamu, özel sektör ve girişimcilik kariyeri seçeneklerine yönelim tercihlerinin sebepleri, her bir kariyer seçeneği için ayrı ayrı belirlenmeye çalışılmaktadır.

Öğrencilerin cinsiyetlerine ve eğitim aldıkları bölüme göre kariyer tercihleri arasında farklılık bulunup bulunmadığının araştırılması da araştırmanın bir diğer amacını oluşturmaktadır.

\section{B. Araştırmanın Yöntemi}

Risk Araştırmada, nitel ve nicel araştırma yöntemlerinin bir arada kullanıldığı karma bir yöntem tercih edilmektedir. Nitel araştırma, gözlem, görüşme ve doküman incelemesi gibi nitel bilgi toplama yöntemlerinin kullanıldığ algıların ve olayların doğal ortamda gerçekçi ve bütüncül bir biçimde ortaya konmasına yönelik bir sürecin izlendiği araştırma olarak tanımlanmaktadır (Yıldırım \& Şimşek, 2006). Araştırmada nitel araştırma yönteminin kullanımı yoluyla, örneklemden derinlemesine ve ayrıntılı bilgi edinilmesi amaçlanmıştır.

Araştırma kapsamında MYO öğrencilerinin kariyer yönelimlerini değerlendirmek amacıyla; bir soru formu hazırlanmıştır. Soru formunda öğrencilere, öncelikle hangi kariyer yönelimini tercih ettikleri sorusu yöneltilmiş, daha sonra seçtikleri kariyer yönelimiyle ilgili üç neden sıralamaları istenmiştir.

Araştırmanın temel amacı doğrultusunda cevabı araştırılan sorular şunlardır:

- MYO öğrencilerinin kariyer yönelimlerinde ilk tercihleri (kamu sektörü-özel sektör-girişimcilik) nedir?

- MYO öğrencilerinin kamu sektörü/özel sektör/girişimcilik kariyerini tercihlerinde etkili olan faktörler nelerdir? 
$\mathrm{Bu}$ sorulara ek olarak, öğrencilerin cinsiyet ve bölümleri temelinde tercihleri arasında farklılık olup olmadığını ortaya koymak amacıyla, aşağıdaki soruların cevabı da araştırılmaktadır.

- Kariyer yönelimi tercihlerinde cinsiyete dayalı bir farklılık var mıdır?

- Kariyer yönelimi tercihlerinde bölüme dayalı bir farklılık var mıdır?

Araştırmada, veri toplama araci olarak kullanılan soru formunun hazırlanmasında, Sezer'in (2013a, 2013b) çalışmalarından yararlanılmıştır. Soru formunun ilk kısmı, cinsiyet ve bölüm bilgilerinden oluşmakta, ikinci kısmında çoktan seçmeli "Mezun olduğunuzda nasıl bir kariyer yolu amaçlıyorsunuz?" sorusu ve altında girişimcilik, özel sektör, kamu sektörü seçenekleri yer almaktadır. Sonraki kısımda öğrencilerden üstte tercih ettikleri kariyer yönelimi ile ilgili üç neden öne sürmeleri istenmiştir. Bu sayede nitel ve nicel araştırma için gerekli veriler elde edilmiştir.

Her öğrencinin, kendi özgün görüşünü kendi sözcükleri ile yazarak güvenirliği artırmak amaciyla, soru formları doldurulurken öğrencilerin birbirleriyle iletişimi kısıtlanmıştır. Ayrıca öğrencilerin kariyer yönelim nedenleri için seçenek verilmeyerek, kendi fikirlerini özgürce ifade etmeleri ve belli bir çerçevede düşünmeyerek, yeni ve çarpıcı nedenler üretmeleri desteklenmeye çalışılmıştır.

Çalışmada elde edilen öğrenci ifadeleri, değiştirilmeden olduğu gibi tablolara yansıtılmaya ve örtük anlam farkları gösterilmeye çalışılmıştır. Ayrıca bu çalışmanın konusu olması açısından, İstanbul Yeni Yüzyıl Üniversitesi Meslek Yüksekokulu'nda girişimcilik dersleri iki dönemlik olup, Bankacılık ve Sigortacılık, Dış Ticaret, Halkla İlişkiler ve Tanıtım, Lojistik, Turizm ve Otel İşletmeciliği ikinci sınıf öğrencilerine, bölüm gereklilikleri doğrultusunda zorunlu veya seçmeli olarak verilmektedir. İlk dönem verilen Girişimcilik-I dersinde; girişimcilik kavramı, girişimcilik türleri, girişimciliğin ekonomik, kültürel ve toplumsal temelleri, iş modeli, iş planı ve girişimcilik süreçleriyle ilgili kavramsal bilgiler anlatılmaktadır. İkinci dönem verilen Girişimcilik-II dersinde bu kavramsal temelden yola çıkılarak, öğrencilerin bir iş fikri geliştirip bunu sırasıyla iş modeli ve iş planına dönüştürmesi beklenmekte, bu doğrultuda da öğrencilerle iş planı öğelerinin pekiştirilmesine yönelik atölye çalışmaları yapılmaktadır.

Çalışmanın saha araştırması bölümünü oluşturan soru formu uygulaması, 21-25 Mayıs 2018 tarihleri arasında yukarıda ifade edilen İstanbul Yeni Yüzyıl Üniversitesi MYO öğrenci gruplarına uygulanmıştır. Araştırmanın ilk kısmında nitel verilerin değerlendirilmesi yapılmış, ikinci kısımda ise cinsiyet ve bölüme dayalı farklılıklar olup olmadığının tespiti için nicel analiz yöntemleri kullanılmıştır.

Veri analizi sırasında, öncelikle soru formu ile elde edilen öğrenci ifadeleri, içerik analizine tabi tutulmuştur. İçerik analizi yöntemi, kalitatif veriyi sistematik bir şekilde ele alarak, bu verinin anlamlandırılmasını kendi çerçevesi içerisinde tanımlayan bir yöntemdir. Belirli bir kodlama ile oluşturulan kategoriler ile bu kategorilerin birtakım özelliklerine göre sinıflandırılması şeklinde uygulanır (Schreier, 2012). Kayıt altına alınan her türlü veri içerik analizine tabi tutulabilir. 
Verinin türü ve kayıt altına alış şekline göre; kelimeler, temalar, karakterler, paragraflar analiz birimi olarak kullanılabilir (Altunışık, Coşkun, Bayraktaroğlu, \& Yıldırım, 2007). Nitel analiz sonrasında, öğrencilerin kariyer yönelimlerinde cinsiyete dayalı bir farklılık olup olmadığının belirlenmesi için $\mathrm{T}$ testi uygulanmıştır. Kariyer yöneliminde bölüme dayalı bir farklılık olup olmadığını belirlemede ise Anova analizinden yararlanılmıştır.

\section{Araştırmanın Evren ve Örneklemi}

Araştırmanın evrenini, Girişimcilik dersi alan MYO öğrencileri oluşturmaktadır. $\mathrm{Bu}$ doğrultuda örneklem grubu ise, İstanbul Yeni Yüzyıl Üniversitesi MYO; Halkla İlişkiler ve Tanıtım, Dış Ticaret, Bankacılık ve Sigortacılık, Turizm ve Otel İşletmeciliği ile Lojistik programı girişimcilik dersi alan son sınıf öğrencilerini kapsamaktadır. Girişimcilik dersi alma durumu, iki dönem boyunca toplam 56 saat süren Girişimcilik I ve Girişimcilik II derslerinin başarılı bir şekilde tamamlanmış olması şeklinde belirlenmiştir.

Araştırmaya, İstanbul Yeni Yüzyıl Üniversitesi MYO bünyesinde bulunan toplam beş programdaki öğrencilerin tamamı $(\mathrm{N}=130)$ dahil edilmiştir. 122 öğrenci soru formunu doldurmuş, 98 soru formundan ise geçerli veri sağlanmıştır $(\mathrm{n}=98)$. Eksik ve hatalı doldurulan soru formları değerlendirilmeye alınmamışıır.

\section{Araştırmanın Kısıtları}

$\mathrm{Bu}$ araştırma, İstanbul Yeni Yüzyıl Üniversitesi MYO öğrencileri örneklemi içinde gerçekleştirildiğinden, bu öğrencilerin görüşleri ile sınırlıdır. Bu kapsamda, tüm girişimcilik dersi alan MYO öğrencileri için genelleştirilememektedir. Çalışmanın en büyük sınırlılığı, örneklemin MYO (122 kişi olmasıdır).

\section{BULGULAR}

Öncelikle öğrencilerin kariyer yönelimi tercihleri belirlenmiş, sonrasında bu tercihin cinsiyete ve bölüme göre farklılık gösterip göstermediğine bakılmıştır.

\section{A. MYO Öğrencilerinin Kariyer Yönelimlerinde İlk Tercihleri (Kamu Sektörü-Özel Sektör-Girişimcilik) Nedir?}

Öğrencilerin kariyer yönelimi tercihleri değerlendirildiğinde; araştırmanın örneklemini oluşturan 98 İstanbul Yeni Yüzyıl Üniversitesi MYO öğrencisinden, 26'sının (\% 26,53) girişimcilik kariyerine, 39'unun (\% 39,80) özel sektör kariyerine ve 33 'ünün $(\% 33,67)$ ise kamu sektörü kariyerine yönelmek istediğ görülmektedir. Öğrenciler arasında en yüksek oranlı kariyer yönelimi tercihi, \% 39,80 ile özel sektör olmaktadır. Bu seçimi sırasıyla, kamu sektörü kariyeri ve girişimcilik kariyeri izlemektedir.

\section{B. MYO Öğrencilerinin Kamu Sektörü/Özel Sektör/Girişimcilik} Kariyerini Tercihlerinde Etkili Olan Faktörler Nelerdir?

Kariyer tercihi seçiminden sonra öğrencilerden seçtikleri bu kariyeri tercih etmelerindeki önemli gördükleri 3 nedeni suralamaları istenmiştir. Sıralanan bu nedenler daha sonra belirli kategoriler altında gruplandırılmıştır. Aşağıda yer alan tablolarda sırasıyla girişimcilik, özel sektör ve kamu sektörünün tercih nedenleri öğrencilerin kendi ifadeleri ile yer almakta ve ait oldukları kategori görülmektedir. 
Tablo 1'de girişimcilik kariyeri için verilen cevaplar bulunmaktadır. Girişimcilik kariyerini tercih eden öğrencilerin ifadeleri değerlendirildiğinde, toplam 14 kategori altında toplandığı görülmüştür. Bu kategorilerin frekanslarına bakıldığında; ilk üç sırada 17 ifade ile kendi işinin sahibi olma isteği, 12'şer ifade ile başarı arzusu ve kazanç gelmektedir. Öğrenci ifadelerinden gruplanan kategorilerin girişimcilik yazını ile paralellik gösterdiği görülmektedir. Bununla birlikte risk iştahı son sıralarda yer almaktadır.

Tablo 1. MYO Öğrencilerinin Girişimcilik Sektörü Kariyerini Tercihlerinde Etkili Olan Faktörler

\begin{tabular}{|c|c|}
\hline Kategori & Frekans \\
\hline $\begin{array}{l}\text { Kendi işinin sahibi olma isteği } \\
\text { - Kendi işimin patronu olmak } \\
\text { - Kendi işimin sahibi olmak / kendi işimi kurmak } \\
\text { - İşimi severek yapmak/ Sevdiğim işi yapmak } \\
\text { - İşsahibi olma isteğim } \\
\text { - Kendi işimin başında olmak }\end{array}$ & $\begin{array}{l}\mathbf{1 7} \\
8 \\
5 \\
2 \\
1 \\
1\end{array}$ \\
\hline $\begin{array}{l}\text { Başarı arzusu } \\
\text { - Mevcut işimizi daha ileriye götürmek } \\
\text { - Kendi hayallerimi gerçekleştirebilmek/çocukluk hayali } \\
\text { - Hayatımı hedefler üzerine odaklamak } \\
\text { - Kendi işimde daha başarılı ve rahat olabileceğimi düşünüyorum } \\
\text { - İnsanlara başarabileceğimi göstermek /Kendi başarımla övünmek } \\
\text { - Hep daha fazla büyümek için çabalamak } \\
\text { - Kariyer hedeflerime kısa zamanda ulaşmak } \\
\text { - Girişimciliğin önü açık ve geliştirilebilir olması } \\
\text { - Gelecekte daha yükseğe çıkacağımı düşünmek }\end{array}$ & $\begin{array}{l}12 \\
1 \\
3 \\
1 \\
1 \\
2 \\
1 \\
1 \\
1 \\
1\end{array}$ \\
\hline $\begin{array}{l}\text { Kazanç } \\
\text { - Gelir seviyemi/kazancımı yükseltmek } \\
\text { - Belli bir maaşa bağlı kalmamak/ sabit ücretten kurtulma isteği } \\
\text { - Finansal /ekonomik özgürlük } \\
\text { - Birikimimi kendi adıma kullanarak daha fazla kar etmek } \\
\text { - Sermaye }\end{array}$ & $\begin{array}{l}12 \\
6 \\
2 \\
2 \\
1 \\
1\end{array}$ \\
\hline $\begin{array}{l}\text { Statü ve güç } \\
\text { - Kendi markamı duyurmak / kendi adımla tanınmak } \\
\text { - Sosyal faktörler / insanlar ile olan ilişkilerim } \\
\text { - Kendi işimde ilerlemek } \\
\text { - Mesleğimin piyasada bir karşılığı olması } \\
\text { - Para olarak değil sürekli müşteri elde etmek } \\
\text { - Türkiye veya dünya çapında işletmenin bilinmesi } \\
\text { - Saygınlığımın olması }\end{array}$ & $\begin{array}{l}9 \\
2 \\
2 \\
1 \\
1 \\
1 \\
1 \\
1\end{array}$ \\
\hline $\begin{array}{l}\text { Bağımsızlık } \\
\text { - Emir almayı sevmemek/Emir altında çalışmamak } \\
\text { - Kendi çalışma ortamımı hazırlayabilmek/yaratmak } \\
\text { - Başka birinin yanında çalışıp kendimi kısıtlamak istemiyorum } \\
\text { - Bağımsız olmak }\end{array}$ & $\begin{array}{l}\mathbf{8} \\
4 \\
2 \\
1 \\
1\end{array}$ \\
\hline $\begin{array}{l}\text { Girişimci kişilik iması } \\
\text { - Çalışmayı ve büyümeyi sevmem } \\
\text { - Kendime güvenimin olması } \\
\text { - Sorumluluk alma isteği } \\
\text { - Lider özellikli olmam } \\
\text { - Kendi özgüvenimin tatmin olması }\end{array}$ & $\begin{array}{l}5 \\
1 \\
1 \\
1 \\
1 \\
1\end{array}$ \\
\hline
\end{tabular}




\begin{tabular}{|c|c|}
\hline $\begin{array}{l}\text { Zaman esnekliği } \\
\text { - Kendi iş saatlerimi belirlemek, zamanımı kontrol altında tutmak } \\
\text { - Çalışma saatlerini kendime göre ayarlarım } \\
\text { - Çalışma saatlerinin esnek olması }\end{array}$ & $\begin{array}{l}1 \\
1 \\
1\end{array}$ \\
\hline $\begin{array}{l}\text { Yenilik yapmak } \\
\text { - Kendi işletmemde yenilikler yapma isteğim } \\
\text { - İnsanlara beklenen alışılagelmiş dışı hizmet vermek } \\
\text { - Farklı ve özgün olabilmek }\end{array}$ & $\begin{array}{l}1 \\
1 \\
1\end{array}$ \\
\hline $\begin{array}{l}\text { Bireysel gelişme } \\
\text { - Alanımla ilgili tüm bilgileri bilmek } \\
\text { - Deneyim kazanmak }\end{array}$ & $\begin{array}{l}1 \\
1\end{array}$ \\
\hline $\begin{array}{l}\text { Kendini gerçekleştirme isteği } \\
\text { - Kendimi gerçekleştirme ihtiyacı }\end{array}$ & 1 \\
\hline $\begin{array}{l}\text { Kişisel geçmiş } \\
\text { - Ailemin issini devam ettirme isteği }\end{array}$ & 1 \\
\hline $\begin{array}{l}\text { Risk iştahı } \\
\text { - Keyifli ve heyecanlı olabilir }\end{array}$ & 1 \\
\hline $\begin{array}{l}\text { Yakınlarına ve topluma faydalı olma } \\
\text { - İnsanlara faydalı ișler yapabilmek }\end{array}$ & 1 \\
\hline $\begin{array}{l}\text { Diğer } \\
\text { - Mekan }\end{array}$ & 1 \\
\hline
\end{tabular}

Tablo 2'de, özel sektörü seçen öğrencilerin bu kariyer yolunu seçmelerinde etkili olan nedenler ve ilgili kategoriler yer almaktadır. MYO öğrencilerinin özel sektörü tercih etme nedenleri incelendiğinde; ilk sırada kazanç, ikinci sırada kariyer fırsatı ve üçüncü sırada ise, çalışma koşullarının geldiği görülmektedir.

Tablo 2. MYO Öğrencilerinin Özel Sektör Kariyerini Tercihlerinde Etkili Olan Faktörler

\begin{tabular}{|c|c|}
\hline Kategori & Frekans \\
\hline $\begin{array}{l}\text { Kazanç } \\
\text { - Daha çok gelir elde etmek } \\
\text { - Maaşları diğer sektörlere göre daha fazla } \\
\text { - Maaş konusunda sıkıntı çekmek istemiyorum } \\
\text { - Aylık kazancın belli olması } \\
\text { - Maddi ve manevi açıdan rahat hissetmek } \\
\text { - Yaptığımız işe oranla zam alma olasılığının daha yüksek olması }\end{array}$ & $\begin{array}{l}22 \\
10 \\
5 \\
2 \\
2 \\
2 \\
1\end{array}$ \\
\hline $\begin{array}{l}\text { Kariyer fırsatı } \\
\text { • Yükselme /terfi imkanları } \\
\text { • Kurumsal bir işletmede müdür/genel müdür olmak } \\
\text { - Kariyer } \\
\text { - Gelecek hazırlamak } \\
\text { • Kariyerim açısından bana olumlu şeyler katması } \\
\text { - Kariyerimde yükselmek için sürekli sinava girmek zorunda } \\
\text { kalmamam } \\
\text { • Kendi mesleğimin olması }\end{array}$ & $\begin{array}{l}21 \\
12 \\
3 \\
2 \\
1 \\
1 \\
1 \\
1\end{array}$ \\
\hline $\begin{array}{l}\text { Çalışma koşulları } \\
\text { - Çalışma imkanlarının uygunluğu } \\
\text { - Daha esnek çalışma ve iş imkanı olduğundan }\end{array}$ & $\begin{array}{l}17 \\
4 \\
2\end{array}$ \\
\hline
\end{tabular}




\begin{tabular}{|c|c|}
\hline $\begin{array}{l}\text { - Mutlu çalışma ortamı } \\
\text { - Çıkış saatlerinin erken olması } \\
\text { - Daha az sorumluluk } \\
\text { - Kurumsallık } \\
\text { - İstediğim işi yapmak } \\
\text { - Tatil imkanları } \\
\text { - Daha az çalışmak } \\
\text { - Çalışma kriterlerime uyması } \\
\text { - İşletmedeki görevlerimin belli olması } \\
\text { - Yol sıkıntısı çekmek istemiyorum }\end{array}$ & $\begin{array}{l}2 \\
1 \\
1 \\
1 \\
1 \\
1 \\
1 \\
1 \\
1 \\
1\end{array}$ \\
\hline $\begin{array}{l}\text { İş olanakları } \\
\text { - İş imkanlarının geniş olması } \\
\text { - Kamuda yer bulamazsam tercih ediyorum }\end{array}$ & $\begin{array}{l}10 \\
9 \\
1\end{array}$ \\
\hline $\begin{array}{l}\text { Kişisel gelişim } \\
\text { • Kendini geliştirme imkanlarının çokluğu } \\
\text { • Bilgi ve tecrübe kazanmak } \\
\text { • Yeteneklerimi kullanma imkanı sağlayacağına ve kendimi } \\
\text { geliştirmeme imkan sağlayacağını düşünüyorum } \\
\text { • Mesleki açıdan bana bilgi ve yenilik katacak olması } \\
\text { • Yeteneklerimizi ve kendimizi kanıtlamak için büyük firsatlar } \\
\text { sunması }\end{array}$ & $\begin{array}{l}\mathbf{1 0} \\
5 \\
2 \\
1 \\
1 \\
1\end{array}$ \\
\hline $\begin{array}{l}\text { Statü ve güç } \\
\text { • Büyük bir firmada çalışmak } \\
\text { • Geniş çevreye sahip olmam } \\
\text { • Özel sektörde çalışarak sağlayacağım bağlantılarla ileride kendi } \\
\text { şirketimi kurmak } \\
\text { • Belli bir markanın altında çalışmak ileriki iş başvurularımda } \\
\text { katkı sağlayacaktır } \\
\bullet \text { Daha saygın bir konumda olmak, ün kazanmak }\end{array}$ & $\begin{array}{l}\mathbf{6} \\
1 \\
1 \\
1 \\
1 \\
2 \\
\end{array}$ \\
\hline $\begin{array}{l}\text { Kişisel geçmiş } \\
\text { • Daha önceki iş tecrübemden ötürü } \\
\text { • Kamu ve girişimciliğin bana uygun olduğunu düşünmüyorum } \\
\text { • Okuduğum bölüme uygun olması }\end{array}$ & $\begin{array}{l}4 \\
2 \\
1 \\
1\end{array}$ \\
\hline $\begin{array}{l}\text { Düşük risk } \\
\text { - Riskli bir yaşantı olmaması } \\
\text { - Gelir konusunda risk yok } \\
\text { - Risk oranı düşük }\end{array}$ & $\begin{array}{l}3 \\
1 \\
1 \\
1\end{array}$ \\
\hline $\begin{array}{l}\text { İş güvencesi } \\
\text { • Özel sektör ölmez bir sektördür }\end{array}$ & 1 \\
\hline $\begin{array}{l}\text { Kişisel özellikler } \\
\text { - Bana uygun olması } \\
\end{array}$ & 1 \\
\hline $\begin{array}{l}\text { Deneyim kazanmak } \\
\text { - İşi iyice öğrenip deneyim sağlamak }\end{array}$ & 1 \\
\hline $\begin{array}{l}\text { Yenilik yapmak } \\
\text { • Yaratıcı zekamı kullanarak sektöre katkıda bulunabileceğimi } \\
\text { düşünüyorum }\end{array}$ & $\begin{array}{l}1 \\
1\end{array}$ \\
\hline
\end{tabular}

Tablo 3'te, kamu sektörünün tercih edilmesinde etkili olan nedenler ve ait olduğu kategoriler sıralanmaktadır. MYO öğrencilerinin kamu sektörünü tercih 
etme sebepleri incelendiğinde; ilk sırada çalışma koşullarının geldiği görülmektedir. Çalışma koşullarının ardından en çok sıralanan nedenler ise, iş güvencesi ve kazanç olmaktadır.

Tablo 3. MYO Öğrencilerinin Kamu Sektörü Kariyerini Tercihlerinde Etkili Olan Faktörler

\begin{tabular}{|c|c|}
\hline Kategori & Frekans \\
\hline Çalışma koşuları & 30 \\
\hline - Mesai saatlerinin belirli olması & 8 \\
\hline - Çalışma saatleri ve izinlerin belirli olması & 7 \\
\hline - Çalışma koşulları & 3 \\
\hline - Disiplin & 2 \\
\hline - İş yoğunluğunun normal olması & 2 \\
\hline - Daha avantajlı olduğunu düşündüğüm için & 2 \\
\hline - Daha esnek çalışma saatleri ve ortamının olması & 1 \\
\hline - Daha verimli çalışma & $\begin{array}{l}1 \\
1\end{array}$ \\
\hline - Mutlu çalışma ortamı & $\begin{array}{l}1 \\
1\end{array}$ \\
\hline - Güvenli ve huzurlu çalışma & 1 \\
\hline $\begin{array}{l}\text { - Sosyal hakları alma güvencesi } \\
\text { - Stressiz olması }\end{array}$ & 1 \\
\hline İş güvencesi & 16 \\
\hline - İș garantisi & 6 \\
\hline - İş güvencesi /devlet güvencesi olmasi & 5 \\
\hline - Devlet bünyesinde çalışma isteği & 3 \\
\hline - İş kaygısı olmaması & 1 \\
\hline - Devamlilik & 1 \\
\hline Kazanç & 11 \\
\hline - Maaş imkanları & 4 \\
\hline - Maddi açıdan olanaklarının uygun olması & 4 \\
\hline - Düzenli maaş & 2 \\
\hline - Çalışmanın karşılığını alma & 1 \\
\hline Kariyer firsatı & 7 \\
\hline - Yükselme imkanlarının fazla olması & 4 \\
\hline - Kariyer imkanlarının geniş olması & 1 \\
\hline - Daha iyi bir iş sahibi olmak & 1 \\
\hline - Kariyerimin üstüne daha çok bilgi ekleme & 1 \\
\hline Statü ve güç & 5 \\
\hline - Saygınlık/Prestij & 3 \\
\hline - Değer görme & 2 \\
\hline Topluma faydalı olma & 3 \\
\hline - İnsanlara hizmet etmek & 1 \\
\hline - Eğitimi seçip insanlara örnek olmak & 1 \\
\hline - Eğitimli bireyler yetiștirip ülkeye faydalı olmak & 1 \\
\hline Başarı arzusu & 3 \\
\hline - Kamu sektöründe daha başarılı olacağımı düşünüyorum & 1 \\
\hline - Kendimi daha başarılı, mutlu hissedeceğimi düşünmek & 1 \\
\hline - Çocukluk hayalim olması & 1 \\
\hline Düşük risk & 2 \\
\hline - Kendi işimi kurup yönetememe endişesi & 1 \\
\hline - Diğer sektörlere göre riskin daha az olması & 1 \\
\hline Diğer & 2 \\
\hline
\end{tabular}




\begin{tabular}{|l|l|}
\hline • Öğrenimime devam etme imkanı sağlaması & 1 \\
- Yeni yerler görme & 1 \\
\hline Kişisel özelliklere uygunluk & $\mathbf{1}$ \\
• Kamu sektöründe daha verimli olacă̆ımı düşünmem & 1 \\
\hline
\end{tabular}

Öğrencilerin kariyer tercihlerinde etkili olan faktörler incelendiğinde; her bir kariyer yönelimi için kazanç faktörünün ilk 3 sırada kendine yer bulduğu gözlenmektedir.

Öğrencilerin kariyer tercihleri ve bu tercihlerinde etkili olan faktörler incelenip kategorize edildikten sonra, cinsiyet ve eğitim aldıkları bölümler açısından tercihlerinde bir farklılık olup olmadığı sorgulanmıştır.

\section{mıdır?}

C. Kariyer yönelimi tercihlerinde cinsiyete dayalı bir farklılık var

$\mathrm{Bu}$ sorunun cevabını bulmak için yapılan $\mathrm{t}$ test analizi sonucunda, anlamlılık değeri 0,006 bulunmuştur. Bulunan $\mathrm{p}$ anlamlılık değeri 0,05 'ten küçük olduğu için, cinsiyet ile kariyer seçimi arasındaki ilişkinin anlamlı olduğunu söylenebilir.

Cinsiyete göre kariyer yönelimi tercihindeki farklılıklara bakıldığında; Tablo 4'te de görüldüğ̈̈ üzere; girişimcilik kariyerine yönelmek isteyen öğrencilerin \% 27 sinin (7 öğrenci) kadın, \% 73'ünün (19 öğrenci) ise erkek olduğu tespit edilmiştir. Özel sektör kariyerine yönelimde bu oranlar, \% 59 (23 öğrenci) kadın ve \% 41 (16 öğrenci) erkek olurken; kamu sektörü yöneliminde ise \% 64 (21 öğrenci) kadın - \% 36 (12 öğrenci) erkek olarak belirlenmiştir.

Tablo 4. Kariyer Yolu Tercihinin Cinsiyete Göre Dağılımı

\begin{tabular}{|c|c|c|c|c|}
\hline & \multicolumn{2}{|l|}{ Mezun olduğunuzda nasıl bir kariyer yolu amaçlyyorsunuz? } & \\
\hline & $\begin{array}{l}\text { Girişimcilik I } \\
\text { Kendi işini kurma }\end{array}$ & Özel sektör & Kamu sektörü & Toplam \\
\hline Kadın & $7(\% 27)$ & $23(\% 59)$ & $21(\% 64)$ & 51 \\
\hline Erkek & $19(\% 73)$ & $16(\% 41)$ & $12(\% 36)$ & 47 \\
\hline Toplam & 26 & 39 & 33 & 98 \\
\hline
\end{tabular}

Bulgular kendi içlerinde değerlendirildiğinde; kadın öğrencilerin \% 45 oranıyla (51 öğrenciden 23'ü) daha çok özel sektör kariyeri tercihinde bulunduğunu, erkek öğrencilerin ise \% 40 oranıyla (47 öğrenciden 19'u) daha çok girişimcilik tercihinde bulunduklarına işaret etmektedir. Keskin (2017)'e göre, kadınlar bir iş kurarak işletirken, erkeklere kıyasla daha fazla zorlukla ve cinsiyete dayalı ayrımcılıkla karşılaşmaktadır. Bu sebeple erkekler daha hızlı girişimci olma kararı alırken, kadınlar daha fazla zamana ihtiyaç duymaktadır. Bu durum kadınları daha kolay meslek sahibi olabilecekleri, kamu ve özel sektöre yöneltmektedir.

\section{midır?}

D. Kariyer yönelimi tercihlerinde bölüme dayalı bir farklılık var

Tablo 5'te, öğrencilerin kariyer yolu tercihlerinin bölümlere göre dağılımı yer almaktadır. MYO öğrencilerinin eğitim aldıkları bölüm açısından kariyer seçimlerinde anlamlı bir farklılık olup olmadığını araştırmak üzere ise Anova analizi uygulanmıştır. Analiz sonucunda, Anova tablosunda $\mathrm{p}$ anlamlılık değeri 0,005 bulunmuştur. $\mathrm{Bu}$ değer 0,05 'ten küçük olduğu için bölümlere göre kariyer seçiminde istatistiksel olarak anlamlı farklılıklar bulunduğu belirlenmiştir.

Farkl11ıkların hangi bölümler arasında olduğunu saptamak üzere Post Hoc testleri uygulanmıştır. Elde edilen bulgulara göre, Bankacılık ve Sigortacılık 
bölümü ile Turizm ve Otel İşletmeciliği bölümü arasında anlamlı farklılıklar olduğu tespit edilmiştir. Bankacılık ve Sigortacılık bölümü öğrencileri, ağırlıklı olarak kamu sektörünü (\%72) tercih etmekte, Turizm ve Otel İşletmeciliği bölümü öğrencileri ise, özel sektör (\%39) ve girişimcilik (\%50) kariyerini tercih etmektedirler. Diğer bölümler arasında anlamlı bir fark bulunmamıştır. Bankacılık ve Sigortacılık bölümü öğrencilerinin başlıca çalışma alanları, bankalar ile sigorta şirketlerinden oluştuğu ve kamu sektöründe iş olanaklarının daha yoğun olduğu, bunun yanı sıra Turizm ve Otel İşletmeciliği bölümü için ise otel işletmeleri, seyahat işletmeleri, yiyecek içecek sektörü çok geniş özel sektör imkanları veya girişimcilik imkanları sunduğundan, iki bölüm öğrencilerinin tercihleri arasından bu yönde anlamlı bir farklılık bulunduğu düşünülebilir.

Diğer bölümler için ise, Diş Ticaret ile Lojistik bölümü öğrencilerinin özel sektöre öncelik verdikleri, Halkla İlişkiler bölümü öğrencilerinin de kamu sektörünü ve ardından özel sektörü tercih ettikleri görülmektedir. Bu durum, bölümlerin içerikleri ve çalışma alanları açısından değerlendirildiğinde, mezun olur olmaz bağımsız bir iş kurmak yerine, daha az riskli görülen kamu ve özel sektöre yönelmek, belli bir süre bu sektörlerde tecrübe edindikten sonra kendi işini kurmak şeklinde bir eğilimle açıklanabilir.

Tablo 5. Kariyer Yolu Tercihinin Bölümlere Göre Dağılımı

\begin{tabular}{|l|c|c|c|c|}
\hline & \multicolumn{2}{|l|}{ Mezun olduğunuzda nasıl bir kariyer yolu amaçlıyorsunuz? } & \\
\hline & $\begin{array}{l}\text { Girişimcilik / Kendi } \\
\text { işini kurma }\end{array}$ & Özel sektör & Kamu sektörü & Toplam \\
\hline Dış Ticaret & 6 & 11 & 3 & 20 \\
\hline Bankacılık ve Sigortacılık & 4 & 1 & 13 & 18 \\
\hline $\begin{array}{l}\text { Halkla İlişkiler ve } \\
\text { Tanıtım }\end{array}$ & 1 & 5 & 7 & 13 \\
\hline $\begin{array}{l}\text { Turizm ve Otel } \\
\text { Isşletmeciliği }\end{array}$ & 7 & 9 & 2 & 18 \\
\hline Lojistik & 8 & 13 & 8 & 29 \\
\hline Toplam & 26 & 39 & 33 & 98 \\
\hline
\end{tabular}

\section{SONUÇ ve ÖNERILLER}

Gençlerin üniversite eğitimi almaya başlamadan önce girişimci olma düşüncesine sahip olmaları, onları mezun olduklarında kendi işini kurmanın yollarını aramaya yöneltmektedir. Bunun dışında üniversite eğitimi sırasında girişimci olma fikrini benimseyen ve eğitimi süresince kendini bu yönde geliştiren ögrenciler de olduğu görülmektedir. Öncelikli olarak Meslek Yüksekokulu öğrencilerinin kariyer yönelimleri ve bu yönelimde girişimcilik tercihinin payının araştırıldığı bu çalışmada, girişimcilik dersi alan İstanbul Yeni Yüzyıl Üniversitesi Meslek Yüksekokulu öğrencilerine bir soru formu yöneltilmiş ve bu soru formundan elde edilen bulgular paylaşı1mıştır. Elde edilen bu bulgulara göre; örneklemi oluşturan toplam 98 öğrenciden, yalnızca 26 tanesinin kendi işini kurmak istediği görülmüştür. Bu sayı çok yüksek olmasa da, aslında girişimcilik gibi büyük oranda belirsizlik ve risk içeren bir kariyer tercihine yöneldikleri düşünüldüğünde iyi bir sayı olduğu söylenebilir. Ayrıca öğrencilerin bölümlerine göre kariyer tercihlerinde farklılık olduğu bulunmuştur. Bankacılık ve Sigortacılık bölümünde okuyan her üç öğrenciden yaklaşık olarak ikisi bir devlet kurumunda 
çalışmak istediğini belirtirken, Turizm ve Otel İşletmeciliği bölümünde okuyan her iki öğrenciden birinin kendi işini kurmak istediği görülmektedir.

MYO öğrencilerinin kamu sektörü ile girişimcilik arasında tercihlerini yaparken; çalışma koşulları, iş güvencesi ve düzenli gelir gibi faktörlerin etkili olduğu görülmektedir. Ancak kamu kurumlarında çalı̧̧mak isteyen öğrencilerin ÖSYM tarafindan belirli aralıklarla gerçekleştirilen merkezi bir sınava girmeleri gerekmektedir. Bu sınavda başarılı olmak için uzun, yorucu ve yüksek maliyetli bir hazırlık süreci kendilerini beklemektedir. Bu çalışmalar için harcanması gereken zaman, emek ve maddi olanakların kişinin kendi işini kurması amacıyla değerlendirilmesi durumunda, başta kendisinin, sonrasında yapılacak olan işin niteliğine göre belirlenecek sayıda çalışanın istihdam edilmesine olanak sağlayabilecektir.

$\mathrm{Bu}$ araştırmadan elde edilen bulgular, genel olarak Türkiye'deki genç nüfusun girişimcilik eğilimlerini tam olarak yansıtmamakla birlikte, mevcut profile yakın sonuçlar çıktığı görülmektedir. Araştırma sonuçlarına göre, kendi işini kurmak isteyen yaklaşık dört öğrenciden yalnızca bir tanesinin kadın öğrenci olduğu tespit edilmiştir. Bu durumda erkek öğrencilerin kadın öğrencilere göre daha çok girişimcilik kariyerine yöneldikleri görülmüştür. Toplum genelinde de kendi işini kurmak isteyen kadın girişimcilerin sayısı, araştırma sonuçlarında olduğu gibi küçük bir kesimi oluşturmaktadır. Üniversite mezunu kadın girişimcilere kamu destekleri konusunda pozitif ayrımcılık yapılıyor olması, sayının kısmen artmasını sağlamakla birlikte, dünya girişimcilik endeksinde alt basamaklarda bulunulduğu görülmektedir.

Girişimcilik dersinin, başta Milli Eğitim Bakanlığı'na bağlı ortaöğretim kurumlarında sonrasında üniversitede ön lisans, lisans, yüksek lisans ve doktora seviyelerinde okutuluyor olmasının büyük bir farkındalık oluşturduğu görülmektedir. Ancak bu farkındalığın, eyleme ve yeni istihdam olanaklarına dönüşmesi için kamu ve özel eğitim kurumlarının, reel sektör sanayi ve oda temsilcilerinin farklı platformlarda bir araya gelmeleri ve daha kalıcı ve sürdürülebilir girişimcilik modellerinin ortaya konulması gerekmektedir.

\section{KAYNAKÇA}

Akın, B.H., \& Demirel, Y. (2015). Entrepreneurship Education and Perception Change: The Preliminary Outcomes of Compulsory Entrepreneurship Course Experience in Turkey. Selçuk Üniversitesi Sosyal Bilimler Enstitüsü Dergisi, Sayı 34, 15-26.

Altunışık, R., Coşkun, R., Bayraktaroğlu, S., \& Yıldırım, E. (2007). Sosyal Bilimlerde Araştırma Yöntemleri: SPSS Uygulamalı (5. Baskı). Sakarya: Sakarya Yayıncılık.

Baumol, W. J. (1968). Entrepreneurship in Economic Theory. The American Economic Review, Cilt 58, Say1 2, 64-71.

Bridge, S., Ken, O., \& Stan, C. (1998). Understanding Enterprise, Entrepreneurship and Small Business. London: Macmillan Press.

Delle, E., \& Amadu, I. M. (2015). Proactive Personality and Entrepreneurial Intention: Employment Status and Student Level as Moderators. International Journal of Small Business and Entrepreneurship Research, Cilt 3, Say1 4, 1-13.

Doğan, E. (2015). The Effect of Entrepreneurship Education on Entrepreneurial Intentions of University Students in Turkey. Istanbul Üniversitesi Işstisat Fakültesi Ekonometri ve Istatistik Dergisi, Sayı 23, 79-93. 
Eğilmez, M. (2018). Değişim Sürecinde Türkiye, Osmanlı'dan Cumhuriyet’e Sosyo-Ekonomik Bir Değerlendirme. İstanbul: Remzi Kitabevi.

Eryılmaz, M. (2015). İşletme: Kuram ve Pratik: Birinci Kısım: İşletme Bilimine Genel Bakış içinde M. Eryılmaz, S. Kaygusuz, \& İ. Efil (Ed.), Işletme: Kuram ve Pratik. Bursa: Ekin Kitabevi, 3-79.

Fayolle, A., Gailly, B., \& Lassas-Clerc, N. (2006). Effect and Counter-Effect of Entreprenurship Education and Social Context on Student's Intentions. Estudios de Economia Aplicada, Cilt 24, Say1 2, 509-523.

Finkle, T. A., Kuratko, D. F., \& Goldsby, M. G. (2006). An Examination of Entrepreneurship Centers in the United States: A National Survey. Journal of Small Business Management, Cilt 44, Say1 2, 184-206.

Galloway, L., \& Brown, W. (2002). Entrepreneurship Education at University: A Driver in the Creation of High Growth Firms? Education \& Training, Say1 44, 398-405.

Güney, S., \& Çetin, A. (2003). Kültürün Girişimciliğe Etkisi ve Türkiye'de Girişimcilik Kültürü. Hacettepe Üniversitesi İktisadi ve İdari Bilimler Fakültesi Dergisi, Cilt 21, Say1 1, 189 210.

İlhan, S. (2003). Sosyo-Ekonomik Bir Fenomen Olarak Girişimciliğin Oluşumunu Etkileyen Başlıca Faktörler. Muğla Üniversitesi Sosyal Bilimler Enstitüsü Dergisi, Sayı 11, 61-79.

Iyer, C. G. (2016). Impact of entrepreneur on the sectoral system of innovation: Case study of the Indian crude oil refining industry. Technological Forecasting and Social Change, Say1 102(January), 102-111.

Keskin, S. (2017). Kadın ve Erkek Girişimciler Arasındaki Farklılıklar. Mersin Üniversitesi Sosyal Bilimler Enstitüsü e-Dergisi, Cilt 1, Sayı 1, 64-76.

Krueger, N. F., \& Carsrud, A. L. (1993). Entrepreneurial Intentions: Applying The Theory of Planned Behaviour. Entrepreneurship \& Regional Development, Cilt 5, Say1 4, 315-330.

Kuratko, D. F. (2005). The Emergence of Entrepreneurship Education: Development, Trends, and Challenges. Entrepreneurship Theory and Practice, Cilt 29, Say1 5, 577-597.

Lorcu, F., \& Erduran, G. Y. (2016). Soul of entrepreneurship, entrepreneurship education? International Journal of Social Sciences and Education Research, Cilt 2, Say1 3, 10301041.

Özdemir, P. (2016). Girişimcilik Eğitimi ve Üniversitelerimiz. Girişimcilik ve Kalkınma Dergisi, Cilt 11, Say1 1, 224-240.

Özdoğan, O. (2019). Endüstri 4.0 Dördüncü Sanayi Devrimi ve Endüstriyel Dönüşümün Anahtarları (3. Bask1). İstanbul: Pusula.

Pan, V. L., \& Akay, C. (2015). Eğitim Fakültesi Öğrencilerinin Girişimcilik Düzeylerinin Çeşitli Değişkenler Açısından İncelenmesi. NWSA-Education Sciences, Cilt 10, Say1 2, 125-138.

Pazarcık, Y. (2016). Üniversitelerimiz Girişimci Yetiştirebiliyor m u?: Üniversite Öğrencilerinin Girişimcilik Algısını/Eğilimini/Özelliklerini Ölçen Araştırmaların Sonuçsal Bir Değerlendirmesi. Sosyal ve Beşeri Bilimler Araştırmaları Dergisi, Cilt 17, Sayı 7, 140-167.

Schreier, M. (2012). Qualitative Content Analysis (1st Edition). Sage Publications.

Sezer, C. (2013a). Girişimcilik Kariyerine Yönelim Nedenleri ve Girişimcilik Dersinin Etkisi Üzerine Bir İçerik Analizi: KTMÜ Örneği. Manas Sosyal Araştırmalar Dergisi, Cilt 2, Sayı 4.

Sezer, C. (2013b). Kariyer Olarak Girişimcilik ve Girişimcilik Niyetini Etkileyen Faktörlerin İçerik Analizi ile Belirlenmesi. Manas Sosyal Araştırmalar Dergisi, Cilt 2, Say1 6

Soylu, A., \& Kepenek, Y. (2008). Meslek Yüksekokulu Öğrencilerinin Girişimcilik Düzeyleri ve Aldıkları Eğitimin Girişimciliğe Olan Katkılarının Belirlenmesi: PAU Honaz Meslek Yüksekokulu Örneği, 2. Uluslararası Girişimcilik Kongresi.

Stevenson, H. H., \& Harillo, J. L. (1990). A pradigm of entrepreneurship: entrepreneurial management. Strategic Management Journal, Say1 11, 17-27.

Varela, R., \& Jimenez, J. E. (2001). The Effect of Entrepreneurship Education in The Universities of Cali. Frontiers of Enterpreneurship Research, Babson Conference Proceedings.

Yelkikalan, N., Akatay, A., Yıldırım, H. M., Karadeniz, Y., Köse, C., Koncagül, O., \& Özer, E. (2010). Dünya ve Türkiye Üniversitelerinde Girişimcilik Eğitimi: Karşılaştırmalı Bir Analiz. KMÜ Sosyal ve Ekonomik Araştırmalar Dergisi, Cilt 12, Sayı 19, 51-59. 
Yıldırım, A., \& Şimşek, H. (2006). Sosyal Bilimlerde Nitel Araştırma Yöntemleri (5. baskı). Ankara: Seçkin Yayıncılık.

Yılmaz, A. S. (2014). Bir Sosyal Değişim Ajanı Olarak Girişimcilik Eğitimi. Zeitschrift für die Welt der Türken, Cilt 6, Say1 1, 297-310.

\section{SUMMARY}

With the paradigm shift in the world; it is known that entrepreneurship contributes to employment, investment, balance of payments and development of countries. For this reason, it is observed that the subject of "entrepreneurship" is starting to take place in the curriculum of vocational schools, undergraduate, graduate and $\mathrm{PhD}$ programs in Turkey, as in other countries of the world. In this study, a questionnaire was applied to determine the career and especially entrepreneurial tendencies of students who take entrepreneurship courses at Istanbul Yeni Yüzyıl University Vocational School. The data obtained from 98 students were analyzed by using the quantitative and qualitative research methods together and some findings were obtained. According to findings, $39,80 \%$ of all students have a career tendencY in private sector while the rate of those who prefer an entrepreneurship career is $26,53 \%$. Moreover, $27 \%$ of the students who want to move towards entrepreneurship career are female and $73 \%$ are male. It was observed that female students prefer mostly private sector and male students choose entrepreneurship. In addition, there are differences between the departments of students in career orientation preferences.

Entrepreneurship has become one of the most important economic phenomena in the world. With the development of this mentality, it is seen that an increase has emerged in the field of entrepreneurship education (Kuratko, 2005). In particular, efforts to change the status of entrepreneurship as a career path that follows the public and private sectors have been on the agenda in the last few decades (Pazarcik, 2016).

When the students graduate, they choose one of the career alternatives that they deem appropriate for various reasons. Many factors are thought to be effective in these choices. In this direction, it is aimed to determine the career orientations of Vocational School students who take entrepreneurship course and the share of entrepreneurship career in these orientations. In addition, the reasons for the preference of the students towards public, private sector and entrepreneurship career options are tried to be determined separately for each career option.

First of all, in this study where the career orientations of the Vocational School students and the share of entrepreneurship preference in this direction were investigated, a questionnaire was sent to the students of the Vocational School of İstanbul Yeni Yüzyll University who took the entrepreneurship course and the findings obtained from this questionnaire were shared. According to these findings; It is seen that only 26 of the 98 students who form the sample want to start their own business. Although this number is not very high, it can be said that it is a good number considering that they tend to pursue a career choice that includes uncertainty and risk to a great extent like entrepreneurship. In addition, it was found that there was a difference in career preferences of the students according to their 
departments. Approximately two out of every three students studying in the Banking and Insurance department stated that they wanted to work in a government institution, while one of the two students studying in Tourism and Hotel Management department wanted to start their own business.

While making the preferences of students between public sector and entrepreneurship; factors such as working conditions, job security and regular income were found to be effective. However, students who want to work in public institutions are required to take a central exam conducted at regular intervals. A long, tiring and costly preparation process awaits them to succeed in this exam. If the time, labor and financial opportunities required for these studies are evaluated in order to establish one's own business, it may enable the employment of a number of employees to be determined primarily according to the nature of the work to be performed afterwards. 